\title{
APPLICATION OF EXFOLIATIVE VAGINAL CYTOLOGY IN CLINICAL CANINE REPRODUCTION - A REVIEW
}

\author{
A. L. ANTONOV \\ Department of Obstetrics, Reproduction and Reproductive Disorders, Faculty \\ of Veterinary Medicine, Trakia University, Stara Zagora, 6000, Bulgaria
}

\section{Summary}

Antonov, A. L., 2017. Application of exfoliative vaginal cytology in clinical canine reproduction - a review. Bulg. J. Vet. Med., 20, No 3, 193-203.

Vaginal cytology has many practical applications in the evaluation of both the normal and abnormal bitch. The objective of this review is to describe the use of exfoliative vaginal cytology as a diagnostic tool in clinical canine reproduction.

Key words: bitch, exfoliative vaginal cytology

\section{INTRODUCTION}

Exfoliative vaginal cytology is the most popular diagnostic method as a part of the gynaecological examination in the bitch (Dreier, 1975; Gunzel-Apel \& Koivisto, 1984; Linde \& Karlson, 1984; Soderberg, 1986a,b; Tammer et al., 1994; Johnson, 2006; Wehrend, 2007; Trasch, 2008; Turmalaj et al., 2011; Groppetti et al., 2012; Leigh et al., 2013; Wehrend et al., 2013). It is based on determination of cyclic cellular changes occurring in the vaginal epithelium as a result of reproductive hormone levels, especially estrogens (Wright \& Parry, 1989). The method is simple and useful even in physiological or pathological conditions of the bitch reproductive system, most frequently the determination of the estrous cycle stages with respect to the optimal breeding time (Turmalaj et al., 2011).

\section{PROCEDURES FOR VAGINAL CELL COLLECTION AND OBTAINING SMEARS}

Vaginal cells could be collected using a sterile speculum and a saline-moistened cotton swab (Wrobel et al., 1975; Wright \& Parry, 1989; Gunzel-Apel, 1993). It is important to prevent contact of the swab with the vestibule, because its cells do not react as quickly to an increase in the blood estrogen concentration as the vaginal mucous membrane (Röttger, 2010).

Collection of vaginal cells may be done using only a cotton swab, without a speculum (Feldman \& Nelson, 1996; Bowen, 2000; Johnston et al., 2001; Kustritz, 
2006; Aydin et al., 2011). The cottontipped end of the swab is passed into the dorsal commissure of the vulva, pressed gently in the caudodorsal direction until it passes over the ischial arch and then the swab is rotated through a complete revolution in each direction and withdrawn (Aydin et al., 2011). The cotton tip is lightly rolled from one end of a glass microscope slide to the other (Feldman \& Nelson, 1996; Johnston et al., 2001; Kustritz, 2006).

Vaginal cells may be collected by inoculation in the vaginal cavity and afterwards aspiration of sterile saline using a plastic catheter (Olson et al., 1988). The liquid is applicated on a glass microscope slide, spread into a thin film and air-dried. The method is minimally invasive, but sometimes a change in cell morphology and lower absolute cell count are observed (Olson et al., 1984a,b; Guyant, 1988).

The smears could be stained using a trichrome or Papanicolaou stain (Papanicolaou, 1942), but the technique is labourious (England \& Concannon, 2002). Many authors reported its use after reducing some steps of the staining (Barret, 1976; Kubicek, 1978; Dumon \& Morel, 1989).

New methylene blue stained smears could be viewed immediately after dye application, but red blood cells are not stained and the smears can not be stored for examination at a later time (Johnston et al., 2001). Other classical staining techniques use stains such as May-Grunwald, Boehringer Mannheim, Pappenheim and Testsimplets ${ }^{\circledR}$ (Gunzel-Apel \& Koivisto, 1984).

Diff-Quick ${ }^{\circledR}$ or Haemacolor ${ }^{\circledR}$ (Merck $\mathrm{KGaA}$ ) is a rapid modified Wright-Giemsa stain easily applicable in the clinical practice. The smears are fixed with methanol and then are stained with the two solutions of Diff-Quick ${ }^{\circledR}$ stain. These smears could be stored for years and examined later (Johnston et al., 2001; Chatdarong et al., 2002).

Aydin et al. (2011) have examined vaginal smears by a direct technique comparing it with classical staining to determine the stages of the sexual cycle of the bitch and found it reliable only in detecting the estrus stage.

\section{EVALUATION OF VAGINAL SMEARS}

The evaluation of vaginal smears is performed with a light microscope at magnifications of 100 to $400 \times$. A minimum of 10 observation fields should be examined (Theise, 2002).

There are different vaginal cell types (Ehlers, 2000). According to most authors, the cells from the vaginal wall are differentiated into basal, parabasal, intermediate, superficial and squamous cells (Rieck \& Kratzheller, 1955; Schutte, 1967; Dreier, 1975; Guyant, 1988; Maneke, 2002; Theise, 2002; Johnson, 2006).

It is generally accepted that vaginal cell types in the smear are related to the stage of the estrous cycle (Bell et al., 1973), which makes the vaginal exfoliative cytology a valuable add-on test in reproductive clinical diagnostics (Christie \& Bell, 1973; Ehlers, 2000).

Basal cells are the smallest cells (10$20 \mu \mathrm{m})$ in the vaginal wall. They are occupied almost entirely by the nucleus and are rarely identified in the smears because they are on the basement membrane (Olson et al., 1984a; Wright \& Parry, 1989).

Parabasal cells are small (15-25 $\mu \mathrm{m})$, round or ovoid with marginal big nucleus. Occasionally, they contain cytoplasmic vacuoles. Parabasal cells may also contain neutrophil granulocytes in the cytoplasm 
and then are called metestrus cells, although they can occur in other cycle stages (Wright \& Parry, 1989) or vaginitis (Olson et al., 1984b).

Intermediate cells exhibit great variations in diameter, so they are differentiated as small $(20 \mu \mathrm{m})$ and large type (30 $\mu \mathrm{m})$ (Rieck \& Kratzheller, 1955; Dreier, 1975; Olson, 1989; Maneke, 2002). Both types have a well shaped nucleus. Small intermediate cells are round to elliptical, but may also have polygonal outline whereas the large type has an irregular and angulated cytoplasmic border (Christie et al., 1972). Intermediate cells have a prominent nucleus. The large type is sometimes confused with superficial cells because they are of similar size (Johnston et al., 2001).

Superficial cells are large cells with a diameter ranging between $30 \mu \mathrm{m}$ (Christie et al., 1972) and $75 \mu \mathrm{m}$ (Concannon \& Digregorio, 1986). They have irregular or angulated borders and dark, pyknotic or faint nucleus. Superficial cells attain their maximum at the time of estrogen peak
(Rieck \& Kratzheller, 1955; Christie et al., 1972; Dreier, 1975; Concannon \& Digregorio, 1986; Johnston et al., 2001; Maneke, 2002; Johnson, 2006).

Squamous cells are large cornified superficial cells which underwent degeneration to become dead anucleated cells (Simmons \& Olson, 1989). They usually stain dark blue-purple during the estrus (Johnston et al., 2001).

Besides the vaginal cells, other types of cells observed in vaginal smears are red blood cells; neutrophil granulocytes (leukocytes); bacteria; tumour cells; clitoral fossa epithelial cells; spermatozoa; giant trophoblastic cells and debris (Maneke, 2002).

\section{CLINICAL APPLICATION OF VAGI- NAL EXFOLIATIVE CYTOLOGY}

\section{Determination of optimum time for} breeding or artificial insemination

Fertility in the bitch is considered to be of great socio-economic importance (Leigh

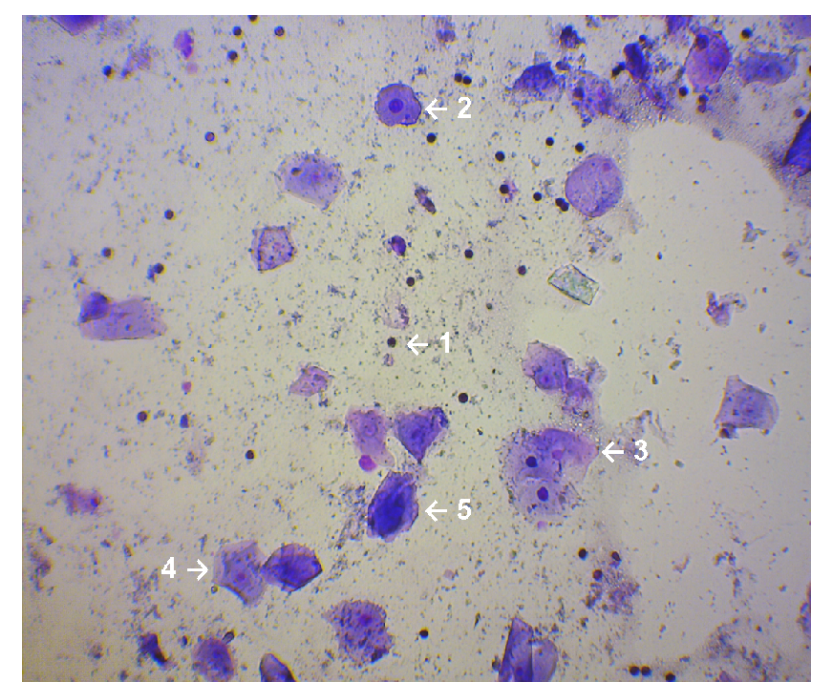

Fig. 1. Vaginal smear of a bitch in proestrus: 1 - red blood cell; 2 - small intermediate cell; 3 - large intermediate cell; 4 - superficial cell; 5 - squamous cell (original, Haemacolor $\AA$, $\times 100$ ). 


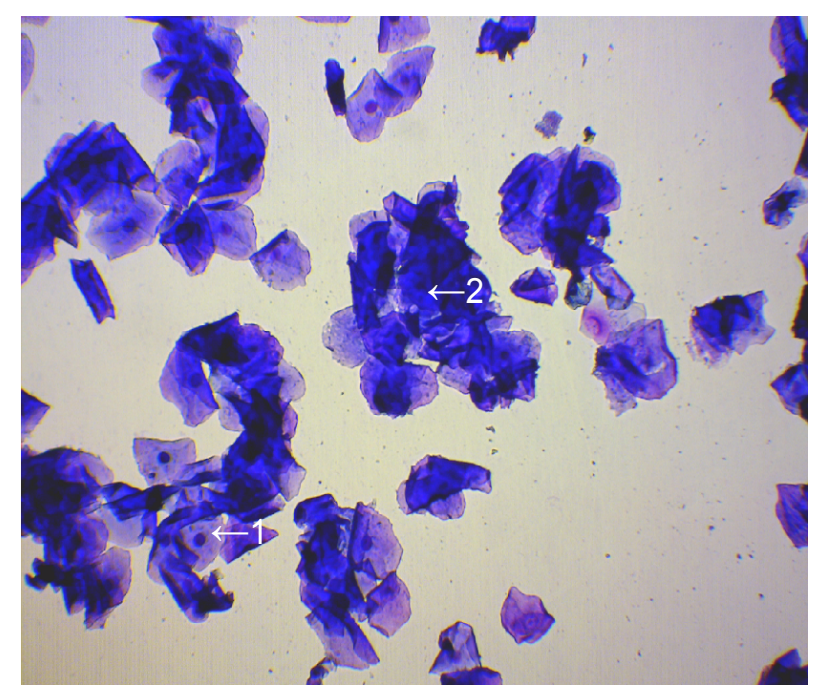

Fig. 2. Vaginal smear of a bitch in estrus: 1 - superficial cell; 2 - squamous cell (original, Haemacolor $\left.{ }^{\circledR}, \times 100\right)$.

et al., 2013). The majority of the bitches presented with history of infertity are in fact fertile (Concannon et al., 1989). The most common cause of conception failure with reported incidence between 40 and $50 \%$ is mistimed breeding time (Zoldag et al., 1993; Johnston et al., 1994).

A gradual shift from parabasal and intermediate to superficial cells occurs during the proestrus. Also, large numbers of red blood cells are present (Fig. 1). The optimum time for natural breeding or artificial insemination is the estrus stage, when the percentage of superficial and squamous cells (Fig. 2) in vaginal smears is above $80 \%$ (Simmons, 1970; Johnston et al., 2001; Srinivas et al., 2004). Breeding or insemination should be done in a two or three days interval until diestrus occurs, as recognised by the appearance of parabasal cells, neutrophils (Simmons, 1970; Srinivas et al., 2004) and the number of superficial and squamous cells decreases by at least 20\% (Holst \& Phemister, 1974) (Fig. 3). Conception rates after a single mating are above $95 \%$ if breeding occurs 3 to 10 days before the onset of cytologic diestrus. The detection of the first day of cytologic diestrus allows determining whether the breeding was done at the appropriate time (Johnston et al., 2001).

Exfoliative vaginal cytology is additionally applied in cases of silent heat, i. e. "white heat", without a vulvar haemorrhagic discharge in the presence of superficial and squamous cells in vaginal smears (Wright \& Parry, 1989; Gunzel-Apel, 1993).

\section{Predicting the whelping date}

If breeding or insemination are done at the optimum time for ultimate conception rates, it is possible to predict with a great accuracy the time of whelping if a series of vaginal smears are taken and the first day of cytologic diestrus is determined. The anticipated time of whelping is 56-58 days, most commonly (93\% of bitches) 57 days after the onset of cytologic diestrus (Holst \& Phemister, 1974; Johnston et al., 2001). 


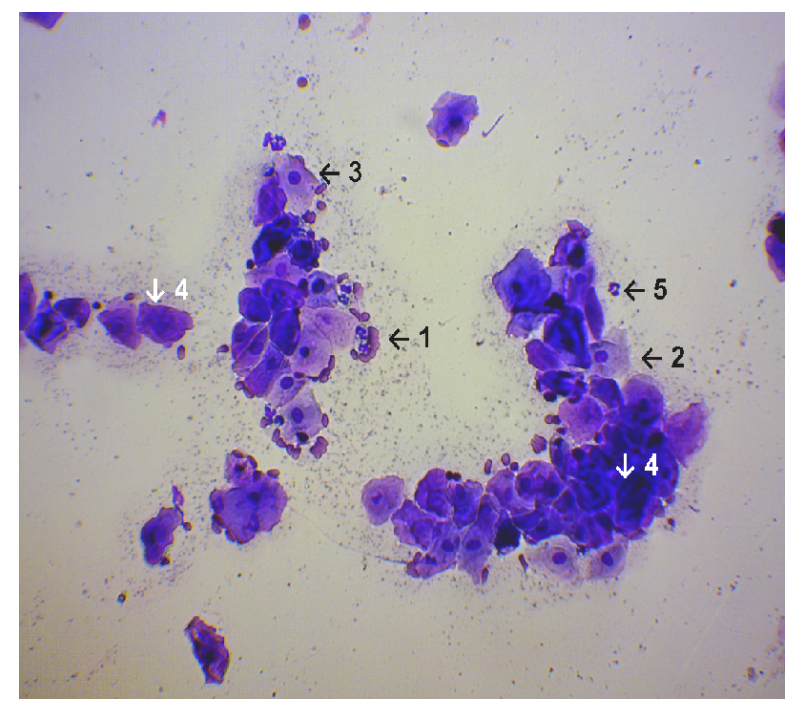

Fig. 3. Vaginal smear of a bitch on the first day of diestrus: 1 - red blood cell; 2 - small intermediate cell; 3 - large intermediate cell; 4 - squamous cells; 5 - neutrophil granulocyte (original, Haemacolor ${ }^{\circledR}, \times 100$ ).

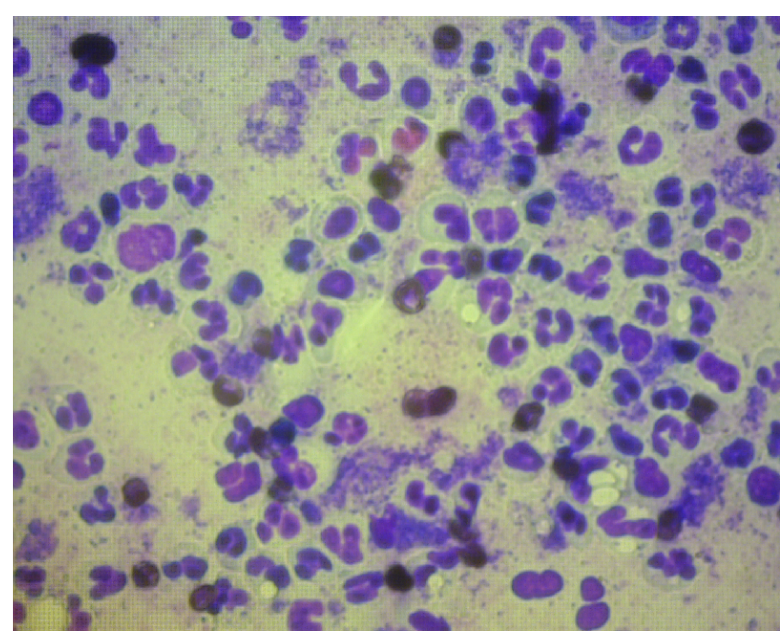

Fig. 4. Vaginal smear from a bitch with vaginitis (original, Haemacolor ${ }^{\circledR}, \times 400$ ).

\section{Vaginitis}

The vaginal smear in dogs with vaginitis (Fig. 4) usually consists of polymorphonuclear leukocytes, with or without bacteria (Johnson, 1991).

\section{Ovarian cysts and tumours}

Bitches with ovarian cysts or granulosa cell tumour have hormonal imbalances such as excessive estrogen production, exhibiting prolonged estrus, vulvar swelling, 
dermatological changes and cystic endometrial hyperplasia with persistent serosanguineous discharge. Vaginal cytology is characterised with more than $80-90 \%$ superficial and squamous cells, similarly to the normal estrus stage, so abdominal ultrasonography is required (Koivisto et al., 2011; Tavasoli \& Solati, 2011).

\section{Ovarian remnant syndrome}

Ovarian remnant syndrome is defined as the presence of functional ovarian tissue left in the abdomen in a previously ovariohysterectomised bitch. The clinical presentation is characterised by signs of proestrus and estrus, including vulvar swelling and haemorrhagic discharge and behavioural changes, such as flagging (Wallace, 1991). Due to the estrogen produced by the remnant, vaginal exfoliative cytologic examination may reveal cornified epithelial cells, similar to normal proestrus and estrus stages (Stone et al., 2003).

\section{Mismating}

Vaginal cytology is the best evaluation method for diagnosing a mismated bitch. Spermatozoa could be found in vaginal smears for 24-36 h after mating (Fig. 5). Lack of sperm does not eliminate mating (Srinivas et al., 2004). It could be impossible to find spermatozoa because there are none present if a mating did not take place or there was in fact a copulation but no sperm have been recovered.

\section{Vaginal tumours}

The transmissible venereal tumour is the most frequently diagnosed neoplasm in the bitch using vaginal exfoliative cytology (Srinivas et al., 2004). Vaginal smears (Fig. 6) contain copious amounts of erythrocytes, neutrophils, lymphocytes, parabasal, intermediate cells and roundto-ovoid shaped cells containing intracytoplasmic vacuoles (Antonov, 2015).

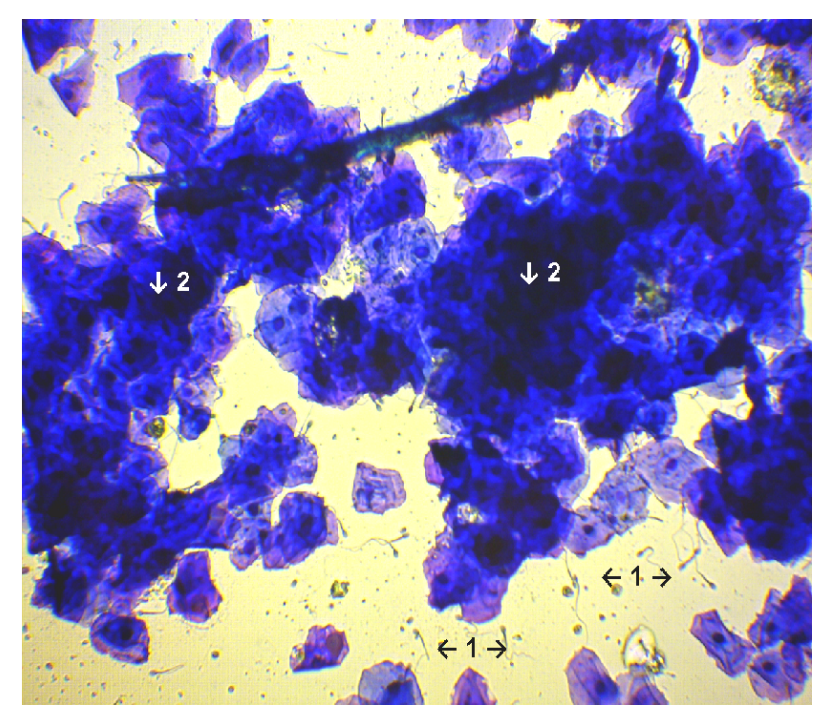

Fig. 5. Vaginal cytology of a bitch an hour after mating: 1 - spermatozoa; 2 - squamous cells (original, Haemacolor ${ }^{\circledR}, \times 100$ ). 


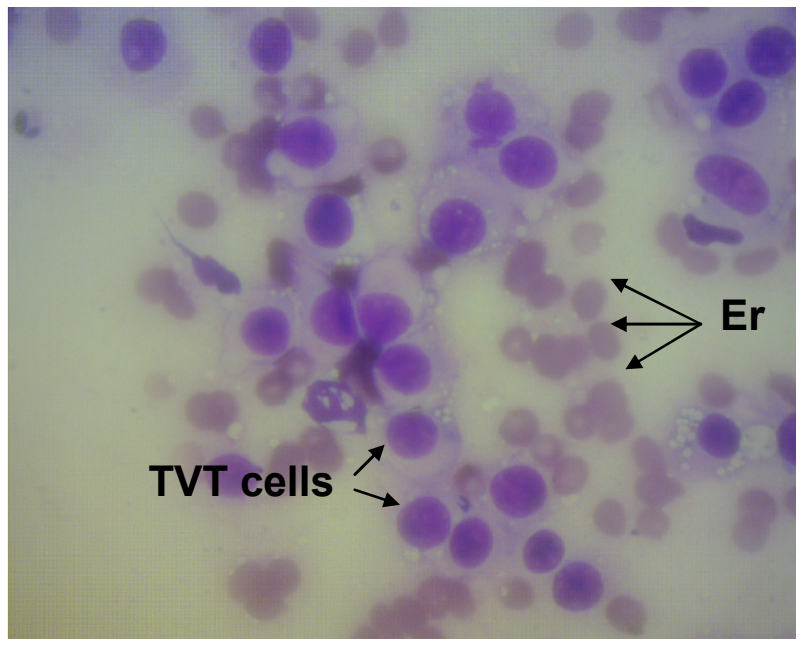

Fig. 6. Vaginal smear of a bitch with transmissible venereal tumour (TVT). Er - erythrocytes (original, Haemacolor ${ }^{\circledR}, \times 400$ ).

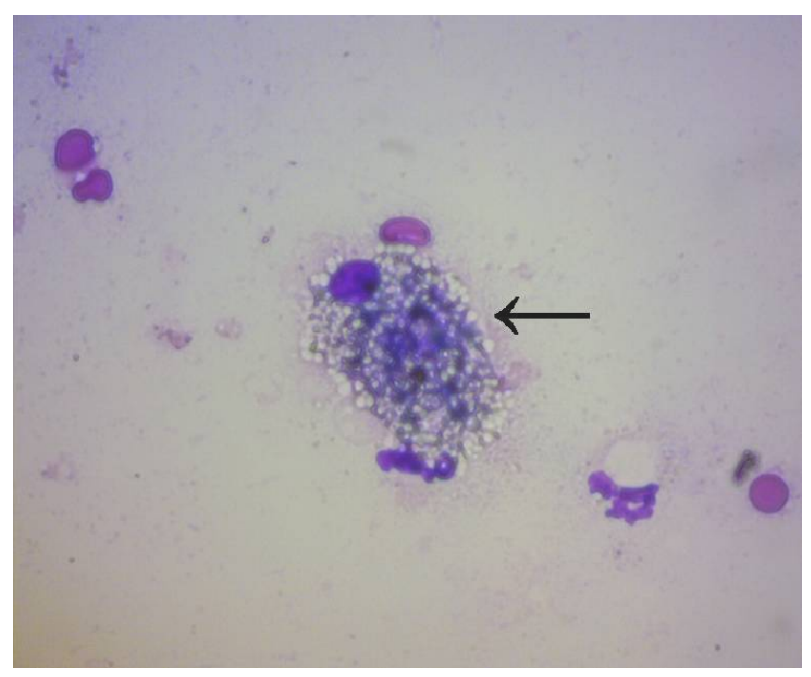

Fig. 7. Trophoblast polynucleated cell in a vaginal smear from a bitch with subinvolution of placental sites (arrow) (original, Haemacolor ${ }^{\circledR}, \times 400$ ).

\section{Subinvolution of placental sites}

Subinvolution of placental sites (SIPS) occurs when the involution of the uterus is delayed and bitches have haemorrhagic uterine discharge that passes from the vulva for several weeks after whelping (Johnston et al., 2001). Normally foetal trophoblasts in bitches may be found in the upper loose connective tissue of the lamina propria for the first 2 weeks after whelping (Al-Bassam et al., 1981). In 
bitches with SIPS these trophoblastic cells do not degenerate and continue to invade the endometrium or even the myometrium, which causes vascular damage to blood vessels and failure of normal endometrial blood vessel thrombus formation (Johnston, 1986). These trophoblast cells are polynucleated and heavily vacuolated and could be observed in the vaginal smears from bitches with SIPS (Dickie \& Arbeiter, 1993) (Fig. 7).

\section{CONCLUSION}

Vaginal exfoliative cytology is a very useful technique because of its simplicity, accessible equipment and the possibility of getting rapid results in clinical canine reproduction. It could be used as a valuable add-on to any reproductive diagnostics in the bitch. Although it is a routine method, there are still some uninvestigated issues, for example related to the effect of copulation and artificial insemination on the dynamics of canine vaginal cell populations.

\section{REFERENCES}

Al-Bassam, M., R. Thomson \& L. O'Donnel, 1981. Normal postpartum involution of the uterus in the dog. Canadian Journal of Comparative Medicine, 45, 217-232.

Antonov, A., 2015. Successful treatment of canine transmissible venereal tumor using vincristine sulphate. Advances in Rese$\operatorname{arch}, \mathbf{5}, 1-5$.

Aydin, I., E. Sur, T. Ozaydin \& D. Dinc, 2011. Determination of the stages of the sexual cycle of the bitch by direct examination. Journal of Animal and Veterinary Advances, 10, 1962-1967.

Barret, R., 1976. Exfoliative vaginal cytology of the dog using Wright's stain. Veterinary Medicine Small Animal Clinic, 71, 12361238.
Bell, E., J. Bailey \& D. Christie, 1973. Studies on vaginal cytology during the canine oestrus cycle. Research in Veterinary Science, 14, 173-179.

Bowen, R., 2000. Techniques for preparing a canine vaginal smear. Fort Collins (USA). Colorado State University. http:/www.vivo.colostate.edu/hbooks/pathphys/reprod/ vc/prep.html (19 April 2016 date last accessed).

Chatdarong, K., N. Kampa, E. Axner \& C. Linde Forsberg, 2002. Investigation of cervical patency and uterine appearance in domestic cats by fluoroscopy and scintigraphy. Reproduction in Domestic Animals, 37, 275-281.

Christie, D., J. Bailey \& E. Bell, 1972. Classification of cell types in vaginal smears during the canine oestrus cycle. British Veterinary Journal, 128, 301-310.

Christie, D. \& E. Bell, 1973. A guide to vaginal cytology in the oestrus cycle of the bitch. Veterinary Annual, 14, 212-215.

Concannon, P. \& G. Digregorio, 1986. Canine vaginal cytology. In: Small Animal Reproduction and Infertility, A clinical Approach to Diagnosis and Treatment. ed T. Burke, Lea \& Febiger, Philadelphia, pp. 96-111.

Concannon, P., J. McCann \& M. Temple, 1989. Biology and endocrinology of ovulation, pregnancy and parturition in the dog. Journal of Reproduction and Fertility. Supplement, 39, 3-25.

Dickie, M. \& K. Arbeiter, 1993. Diagnosis and therapy of the subinvolution of placental sites in the bitch. Journal of Reproduction and Fertility. Supplement, 47, 471-475.

Dreier, C., 1975. Vaginal cytology: Studies on the possibility of diagnosing normal and pathological cycles in the bitch. Wiener Tierarztliche Monatsschrift, 62, 188.

Dumon, C. \& C. Morel, 1989. Use of the Diagnoestrus RAL kit for staining vaginal smears in bitces. Pratique Médicale et Chirurgicale de l'Animal de Compagnie, 24, 49-53. 
Ehlers, J., 2000. Standardisierung und Reproduzierbarkeit der Vaginalzytologie bei der Hundin und ihr Einsatz bei der Bestimmung des optimalen Belegungszeitraumers. Diss, Munchen.

England, G. \& P. Concannon, 2002. Determination of the optimal breeding time in the bitch: basic considerations. In: Recent Advances in Small Animal Reproduction, eds P. Concannon, G. England \& J. Verstegen, International Veterinary Information Service, Ithaca, New York, Usa.

Feldman, E. \& R. Nelson, 1996. Canine and Feline Endocrinology and Reproduction. $2^{\text {nd }}$ edn, W.B. Saunders Company, Philadelphia, USA.

Groppetti, D., A. Pecile, C. Barbero \& P. Martino, 2012. Vaginal bacterial flora and cytology in proestrus bitches: Role on fertility. Theriogenology, 77, 1549-1556.

Gunzel-Apel, A. \& P. Koivisto, 1984. Aktuelles zum Sexualzyklus der Hundindiagnostische Moglichkeiten durch vaginalzytilogische Untersuchungen mittels Testimplets. Der Praktische Tierarzt, 2, 161-172.

Gunzel-Apel, A., 1993. Fruchtbarkeitskontrolle bei der Hundin. Vet Reihe.

Guyant, L., 1988. Canine vaginal cytology. Veterinary Techniques, 9, 513-520.

Holst, P. \& R. Phemister, 1974. Onset of diestrus in the beagle bitch: Definition and significance. American Journal of Veterinary Research, 35, 401-406.

Johnson, C., 1991. Diagnosis and treatment of chronic vaginitis in the bitch. Veterinary Clinics of North America: Small Animal Practice, 21, 523-531.

Johnson, C., 2006. Fortpflanzungsstorungen. In: Labordiagnostik in der Kleintierpraxis, eds M. Willard \& H. Tvedten, Urban \& Fischer Verlag, Munchen, pp. 377-383.

Johnston, S., 1986. Subinvolution of placental sites. Current Veterinary Theriogenology, 9, 1231-1233.

Johnston, S., P. Olson \& M. Root, 1994. Clinical approach to infertility in the bitch.
Seminars in Veterinary Medical Surgery, 9, 2-6.

Johnston, S., M. Kustritz \& P. Olson, 2001. Canine and Feline Theriogenology, $2^{\text {nd }}$ edn, W. B. Saunders Company.

Koivisto, M., I. Carvalho, J. Carreira, J. Trevizan, G. Machado, F. Sueiro, L. Ciarlini \& P. Gomes, 2012. Granulosa cell tumor in a bitch-case report. In: Proceedings of the $7^{\text {th }}$ International Symposium on Canine and Feline Reproduction-ISCFR, Whistler, Canada.

Kubicek, J., 1978. A simplified vaginal smear method for hormonal cytodiagnosis in the bitch. Kleintierpraxis, 23, 259-262.

Kustritz, M., 2006. Collection of tissue and culture samples from the canine reproductive tract. Theriogenology, 66, 567574.

Leigh, O., L. Raji, \& E. Diakodue, 2013. Detection of standing heat in bitches: Application of vaginal cytology. World Journal of Life Science and Medical Research, 3, 21-25.

Linde, C. \& I. Karlson, 1984. The correlation between the cytology of the vaginal smear and the time of ovulation in the bitch. Journal of Small Animal Practice, 25, $77-$ 82.

Maneke, N., 2002. Untersuchung zur Beschreibung von Vaginalzellen der Hündin als ein Beitrag zur objektiven Zyklusdiagnostik. Veterinary Medicine Dissertation, Berlin.

Olson, P., M. Thrall \& P. Wykes, 1984a. Vaginal cytology: Part I: A useful tool for staging the canine estrous cycle. Compendium of Continuous Education of the Practicing Veterinarian, 6, 288-298.

Olson, P., M. Thrall \& P. Wykes, 1984b. Vaginal cytology. Part II. Diagnosing canine reproductive disorders. Compendium of Continuous Education of the Practicing Veterinarian, 6, 385-390.

Olson, P., T. Thomas, P. Husted \& T. Nett, 1988. Clinical Evaluation of Infertility in the Bitch. Clinical Signs and Diagnosis in Small Animal Practice, ed R. B. Ford, 
Application of exfoliative vaginal cytology in clinical canine reproduction - a review

Churchill Livingstone, New York, pp. 631-654.

Olson, P., 1989. Exfoliative cytology of the canine reproductive tract. In: Proceedings of the Annual Meeting of the Society for Theriogenology, Coeur d'Alene, ID, September 29-30. Nashville, Society for Theriogenology.

Papanicolaou, G., 1942. A new procedure for staining vaginal smear. Science of New York, 95, 438.

Rieck, G. \& Kratzheller, K., 1955. Zytologie des desquamierenden Vaginalepithels der Hündin und ihre Anwendung für die Zytodiagnostik. Zentralblatt der Veterinärmedizin, 2, 82-101.

Rottger, K., 2010. Untersuchungen zur durchfuhrung der exfoliativen vaginalzytologie bei der hundin. Dissertation.

Schutte, A., 1967. Canine vaginal cytology - I. Technique and cytological morphology. Journal of Small Animal Practice, 8, 301306.

Simmons, J., 1970. The vaginal smear and its practical application. Veterinary Medicine/ Small Animal Clinician, 65, 369-373.

Simmons, J. \& P. Olson, 1989. Nomenclature for small animal theriogenology. Society for theriogenology Newsletter, July/August.

Soderberg, S., 1986a. Canine breeding management. Veterinary Clinics of North America: Small Animal Practice, 16, 419-433.

Soderberg, S., 1986b. Vaginal disorders. Veterinary Clinics of North America: Small Animal Practice, 16, 543-559.

Stone, E., C. Cantrell \& N. Sharp, 2003. Ovary and uterus. In: Textbook of Small Animal Surgery, $2^{\text {nd }}$ edn, ed D. Slatter, W. B. Saunders Company, Philadelphia, USA, pp. 1293-1308.

Srinivas, M., N. Lakshmi Rani, K. Suresh \& M. Sreenu, 2004. Vaginal exfoliative cytology as a tool in diagnosing reproductive disorders in bitches. Intas Polivet, 5, 354-356.
Stone, E., 2003. Textbook of Small Animal Surgery, $3^{\text {rd }}$ edn, W. B. Saunders, Philadelphia, p. 1498.

Tammer, I., K. Blendinger, A. Sobiraj \& H. Bostedt, 1994. Uber den Einsatz der exfoliativen Vaginalzytologie im Rahmen der gynakologischen Befunderhebung bei der Hundin. Tierarztliche Praxis, 22, 199207.

Tavasoli, A. \& A. Solati, 2011. Granulosa cell tumor of the ovary in dog: Case Report from Teheran. Journal of Cell and Animal Biology, 5, 66-68.

Theise, B., 2002. Unterstutzung zur Entwicklung eines computergestutzten Lernprogramms zu den Grundlagen der Gynakologie bei der Hundin. Dissertation.

Trasch, K, 2008. Gynakologie bei der Hundin. CVE Kleintier, 2, 9-14.

Turmalay, L., S. Duro, E. Lika \& V. Ceroni, 2011. The hormonal control of estrus in bitches. Journal of Animal and Veterinary Advances, 10, 2447-2449.

Wallace, M., 1991. The ovarian remnant syndrome in the bitch and queen. Veterinary Clinics of North America: Small Animal Practice, 21, 501-507.

Wehrend, A., 2007. Durchfuchrung und Interpretation der exfoliativen Vaginalzytologie bei der Hundin. Spektrum Tiermedizin 9, Veterinarsspiegel Verlag, Berlin.

Wehrend, A., K. Von Plato \& S. GoerickePesch, 2013. Die exfoliative vaginalzytologie bei der hundin-indikationen, durchfuhrung, interpretation. Tierarztliche Praxis, 4, 267-274.

Wright, P. \& B. Parry, 1989. Cytology of the canine reproductive system. Veterinary Clinics of North America: Small Animal Practice, 19, 851-874.

Wrobel, K., M. El-Etreb \& P. Gunzel, 1975. Histochemical and histological studies of the vagina of the beagle during various functional conditions. Acta Histochemica, 52, 257-270. 
Zoldag, L., Kecskemethy, S. \& P. Nagy, 1993. Heat progesterone profiles of bitches with ovulation failure. Journal of Reproduction and Fertility. Supplement, 47, 561-562.

Paper received 15.01.2016; accepted for publication 08.04.2016

\section{Correspondence:}

Assistant Professor Dr. Anton Antonov PhD Department of Obstetrics, Reproduction and Reproductive Disorders

Faculty of Veterinary Medicine,

Student's Campus,

6000 Stara Zagora, Bulgaria

tel. +35942699514

e-mail: anton.antonov@abv.bg 